\title{
Carbon Capture Analysis in Two Forage Systems as a Tool for Mitigating Global Warming. Study Case: Sumaco Biosphere Reserve - Ecuador
}

\author{
Jimenez G. Alejandra, Jimenez Y. Santiago, and Jimenez G. Cristhy
}

\begin{abstract}
Global warming is the phenomenon in which the accumulation of greenhouse gases in the atmosphere produces the increase of the global average temperature. Carbon dioxide is one of the main responsible for the "extended" greenhouse effect. The release of this gas mostly obeys to anthropogenic activities effect. Plants contribute to store the atmospheric $\mathrm{CO}_{2}$ through the photosynthesis and biomass production. The forests capability to store carbon is well known around the world, however in Ecuador there is insufficient information about this topic. This paper presents the research conducted in order to quantify the carbon stored in two soil use systems. Pastures with and without shade were analyzed during the study. Both soil use systems are located in the Sumaco Biosphere Reserve. Temporary sample plots of $500 \mathrm{~m}^{2}$ were installed in three towns of Napo Province. The sample plots were divided in several smaller plots and trial pits. All storage components of woody and herbaceous strata were analyzed. The obtained data were expressed in tons per hectare of estimated $\mathrm{CO}_{2}$. The results of the study showed on one hand, that the main storage component in both soil use systems was the soil; whereas, forage production was higher in system without shade.
\end{abstract}

Index Terms-Biomass, carbon dioxide, carbon storage, global warming, pastures with shade, pastures without shade.

\section{INTRODUCTION}

One of the main problems facing the world is climate change. The main manifestation of this problem is the increase of the global average temperature. This problem has worsened between 1970 and 2000.During this period, an increase of $0.6{ }^{\circ} \mathrm{C}$ was recorded in the global temperature [1]. Global warming is attributed to the accumulation of greenhouse gases (GHG) in the atmosphere, such as carbon dioxide $\left(\mathrm{CO}_{2}\right)$, methane, nitrous oxide, among others.

The GHG commonly derived from the use of fossil fuels, industrial processes, livestock systems (digestive process of these animals also generates big quantities of methane that is released into the atmosphere [2]. The constant pasture degradation, deforestation and changes in soil use, also contribute significantly to the increase in atmospheric $\mathrm{CO}_{2}$ [3].

$\mathrm{CO}_{2}$ is the main gas responsible for the greenhouse effect. The majority of the emitted gas has an anthropogenic origin.

\footnotetext{
Manuscript received May 30, 2014; revised July 15, 2014

Jimenez G. Alejandra is with the Escuela Superior Politécnica del Ejército, Quito, Ecuador (e-mail: a_jimenez@espe.edu.ec).

Jimenez Y. Santiago and Jimenez G. Cristhy are with the Escuela Superior Politécnica de Chimborazo, Riobamba, Ecuador (e-mail: \{fahureguy.jimenez, c_jimenez\}@espoch.edu.ec).
}

Almost the 80 to $85 \%$ is the result of using fossil fuels [4], whereas 20 to $25 \%$ is caused by changes in the soil use and deforestation. $\mathrm{CO}_{2}$ has a high durability in the atmosphere (100-300 years), therefore, even if emissions stopped now, $\mathrm{CO}_{2}$ concentrations will not decrease but they will remain stable for at least more than a century. Within this perspective, and according to the guidelines established in the Kyoto Protocol, there are two alternatives that lead to the reduction of these gases. On one hand there is the commitment to substantially reduce anthropogenic $\mathrm{CO}_{2}$ emissions, and on the other hand highlights the need to create, maintain and/ or protect ecosystems which are a carbon sink. It is expected that the idea of safeguarding the integrity of natural environments is conjugated with the development of local and international mitigation projects framed on the principle of the clean development mechanism $(\mathrm{CDM})$.

Current numbers show that Latin America and the Caribbean hold57\% of forests worldwide approximately [5]. In Ecuador forests cover the $42 \%$ of the total area of the country, where $80 \%$ are located in the Amazon region [6] however, despite its biodiverse wealth, is one of the countries with the highest deforestation rate. Currently the Government has established rules for controlling the massive loss of Ecuadorian forests and also has declared as priority strategy the maintenance and protection of areas called "Biosphere Reserves".

The Sumaco Biosphere Reserve (SBR), located in the northeastern part of the Amazon region, has an extraordinary biodiversity. It has 7 of the 25 life zones and it is located in 5 of the 7 altitudinal thresholds established by Holdrige [7]. According to the current soil use in the SBR, the soil used for forage production occupies $8 \%$ of the total territory. The adequate management of these systems could contribute to enhance the natural beauty of the place and also contribute significantly to capture of $\mathrm{CO}_{2}$ through environmental services poorly investigated in Ecuador.

The importance of livestock ecosystems is justified because from 12 to $15 \%$ of carbon emitted in more than 5 decades could be controlled by forestall and forage ecosystems [8]. Due to progressive environmental deterioration arises the need for sustainable alternatives that facilitate the assessment of the environmental services that ecosystems provide.

This paper presents the study of carbon sequestration which was analyzed as an environmental service in two soil use systems oriented to livestock sector in SBR. The first soil use system was a common forage system (without shade) and the second was a silvopastoral system (with shade). Each one 
of the selected ecosystem allows generating economic gains based on livestock activities, and also they are capable for giving environmental benefits to the communities that are responsible for manage and conserve them.

Even though, the monitoring of carbon sequestration constitutes an essential tool for climate change mitigation projects, few researches have been conducted in Ecuador. The present study intends to contribute with the biodiversity conservation and to generate alternatives for guiding the producer in the selection of the best treatment for the pastures. It is also expected that this research can provide the necessary guidelines for executing development projects or environmental policies.

\section{STUDY OF THE ART}

The increase of the emission of greenhouse gases (GHG) and the resulting climate change could significantly affect the environmental in the XXI century. Although the real consequences are still uncertain, it is expected serious negative effects for the human life. Then, it is essential that some measures for reducing greenhouse gas emissions and increasing carbon sequestration in soils and biomass are been taken into account.

More appropriated strategies and policies must be developed in order to generate a sustainable management of agriculture, livestock and forests. One alternative is based on carbon sequestration in soils or in ground biomass, especially on soil used for agriculture or forestry. From Kyoto Protocol this strategies are known as Land Use Change on Land Use and Forestry (LULUCF) [9].

\section{A. Global Carbon Cycle}

The global carbon cycle is recognized as one of the main biogeochemical cycles due to it participated in the regulation of $\mathrm{CO}_{2}$ concentration in the atmosphere. Increasing concentrations of $\mathrm{CO}_{2}$ in the atmosphere are an relevant contribution to climatic change [10].

Forests are one of the most important stores in the world and they are responsible for most of carbon flows between soil and atmosphere. The fundamental processes of these flows are photosynthesis $\left(\mathrm{CO}_{2}\right.$ capture to transform carbohydrate) and respiration (oxidation of carbohydrates to release $\mathrm{CO}_{2}$ ) [11]. During thousands of years these two flows have been balanced.

\section{B. Carbon Storage}

Carbon sequestration in forests refers to the storage of carbon in soil and all vegetation types. Plants absorb carbon dioxide and convert it into carbohydrates. Due to the lower total leaf area (leaf index), herbaceous species consume less carbon dioxide than trees. In any of these species, carbon storage is not restricted to the aerial parts of the plants, but also in roots and soil. They can store big amounts of carbon for a long period of time. In other words, in a regular wood forest, a significant amount of absorbed carbon is moved to the roots and soil [12]. A young forest with net growing is able to capture and store $\mathrm{CO}_{2}$, whereas a mature forests with few growing is only able to store carbon and unable to capture it. Hence, mature forests are equally important because they are capable for retaining the $\mathrm{CO}_{2}$ that was already absorbed.

Pastures without shade are composed by different kind of herbaceous vegetation such as grasses, ferns, vines, and small plants. This kind of vegetation is present in every type of soil use (forestry, agriculture). Pastures with shade have a similar composition but, they include some randomly distributed trees. Despite the proportion of woody vegetation may be small, this does not mean that it is not relevant in the structure of these ecosystems [13].

\section{Estimation of Carbon Sequestration}

The above ground biomass in both trees and shrubs can be calculated from two commonly used methods for estimating biomass: the direct and the indirect method. First one is also known as destructive method because it involves felling trees activities in order to determine the biomass through the direct weighing of each component [13]. The obtained values are used to build allometric equations and models of growing and biomass. This method involves biomass harvesting of all trees in a known area. The collected samples are dried and weighed. Subsequently, the value of dried biomass is converted to carbon by applying a conversion factor of 0.5 because it is established that the carbon content reaches almost $50 \%$ of the biomass [14].

The indirect method consists in using allometric equations or expansion factors [15] that currently exist in the literature. Equations were generated from the direct method, in order to perform the necessary calculations for biomass projects. In this case, it is only necessary to measure the most important variables in the field (e.g. diameter and/or height), and subsequently include the variables in the selected equation.

The carbon storage of pastures is determined through destructive sampling (cut of the entire sampled area) because it is necessary to capture the complete variability in herbaceous biomass. It is important to highlight that the sampling does not damage the ecosystem, due that the cut area is relatively small.

\section{Carbon Stored in Soil Use Systems Relevant for Livestock}

According to the Kyoto Protocol, the process for capturing carbon allows stimulating relevant changes in the soil use, but also presents a positive impact over the environmental and agricultural properties and the biodiversity. The benefits could involve the increase of the soil fertility and productivity. The valuation of the environmental services will also allow that agricultural practices be more sustainable and will help to prevent the degradation of soil resources.

Grazing lands (pastures with and without shade) as well as forests play an important role in the carbon sequestration. Currently, they are included in the Article 3.4 of the Kyoto Protocol. From the environmental point of view, the relevance of this kind of ecosystems lies in its participation for the regulation of atmospheric carbon. According to Food and Agriculture Organization (FAO), the rangeland occupies almost 3200 million hectares worldwide and they are capable to store between 200 and $420 \mathrm{Pg}$ of $\mathrm{CO}_{2}(1 \mathrm{Pg}=1000$ million tons)[16].The majority of stored carbon is located underground; therefore, it stays in a relatively stable state. It is important to mention that rangeland soil is capable to store the same quantity of carbon that a forest soil [16]. 


\section{CASE STUdy}

\section{A. Geographic Location}

In order to identify the potential for carbon storage in two forage ecosystems (with and without shade), the Sumaco Biosphere Reserve (SBR) was selected as case study. This Reserve is located in the following geographical coordinates:

- Latitude: $77^{\circ} 05^{\prime}$

- Longitude: $01^{\circ} 15^{\prime}$

The SBR is composed by two zones: 1) the core zone which is the area of strict protection and 2) the support area which is divided in buffer and transition subzones. The transition subzone has a surface area of 548,051.52 hectares. The sustainable management of natural resources is essential in this subzone. In order to conduct the present research, the Napo province belonging to transition subzone was selected as study area.

\section{B. Weather Conditions}

Taking into account the similar conditions of climate, altitude, rainfall and accessibility, 3 of the 5 towns belonging Napo province were selected. The selected towns were: Arosemena Tola, Tena and Archidona. These towns have a percentage of 51,36 and $50 \%$ of the area in the SBR respectively [17]. Table I summarizes the characteristics of every town of the study area.

TABLE I: MAIN CHARACTERISTICS OF THE STUDY AREA

\begin{tabular}{lccc}
\hline \hline Characteristic & ArosemenaTola & Tena & Archidona \\
\hline Temperature Average & $26^{\circ} \mathrm{C}$ & $26^{\circ} \mathrm{C}$ & $25^{\circ} \mathrm{C}$ \\
Altitude Transition Area & $400-800 \mathrm{masl}$ \\
Precipitation transition zone & \multicolumn{2}{c}{$4000-6000 \mathrm{masl}$} \\
Climate & Warm humid and pre humid \\
Soil type & \multicolumn{2}{c}{ Entisols, Inceptisols } \\
\hline \hline
\end{tabular}

\section{Selection and Establishment of the Study Sites}

Some criteria were considered in order to identify the farms that will be selected as study sites:

- Main production activity of the farm is livestock

- Pasturing as main food source for livestock

- Age of pasture must be 2-3 years

- Availability of pastures with shade (silvopastoral)

- Availability of pastures without shade

- Availability of pasture before pasturing

- Willingness of the owners of the farms

According to the application of these criteria, 15 farms were chosen. The soil use systems (SUS) that were selected as objet of study were: pastures with and without shade.

In this research, pastures with shade are considered all those ecosystems in which palms, trees or shrubs, whether these timber, fruit, protein banks, among others are scattered in a forage plantation between 2 and 3 years old, with a tree density of 140-250 trees/ha. This density corresponds to the moderately scattered woody vegetation category established in the MacDicken categorization [18].

The most important specification of without shade pastures SUS was the age between 2 and 3 years. This ecosystem is characterized by the absence of trees. It was not considered the used forage species as a constraint, because the adaptation of the species depends on several kinds of conditions such as soil, humidity, solar radiation, among others. There are species that are better adapted than other, and the selection criterion depends of the farmer. Therefore, forage species was not specified.

\section{ResearchMethod}

\section{1) Sampling intensity}

In each one of the selected farms, temporary sample plots (TSP) were established. Sampling intensity was defined based on the total area of the towns located in the SBR. In order to calculate the TSP, a sampling intensity of $4.5 \%$ was considered.

The equation for estimating the number of TSP was taken from[18], and it is presented in (1):

$$
n=((S I \times S A)) /(T A \times 100)
$$

where, $n$ : number of TSP (temporary sample plots), SI: sampling intensity $(\%), S A$ : total system area $\left(\mathrm{m}^{2}\right), T A$ : TSP area $\left(\mathrm{m}^{2}\right)$.

The area of the TSP used in the research was $500 \mathrm{~m}^{2}$. According to Mac Dicken [18], this size is recommended for inventorying forage systems with scattered trees, with a tree density of 140-250 trees/ha. Therefore, it was established 30 TSP by each soil use system.

\section{2) Temporary sample plots (TSP)}

Data collection was carried out in circular plots of $500 \mathrm{~m}^{2}$. They were randomly placed within the soil use systems. Additionally, 7 subplots of $0.25 \mathrm{~m}^{2}$ were also randomly established within circular plot. Fig. 1 depicts the distribution scheme of the defined temporary sample plots.

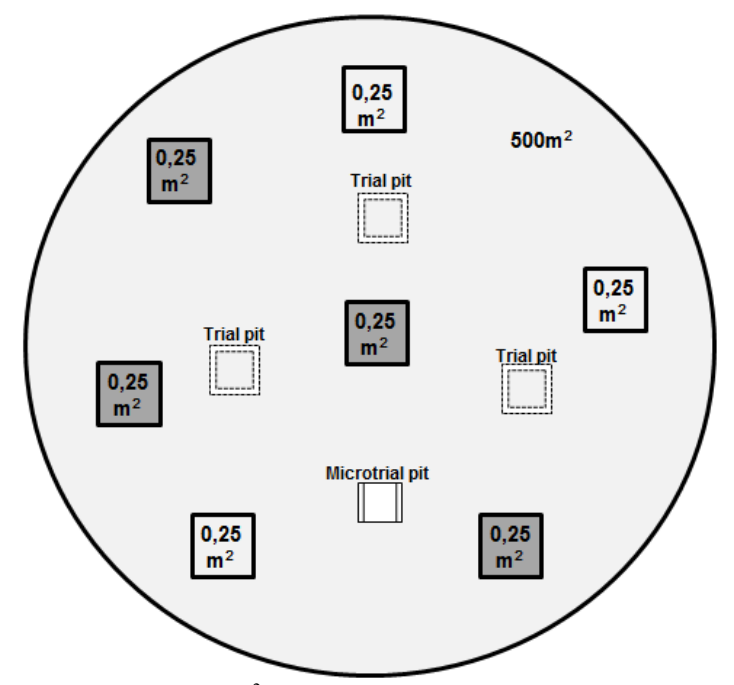

1 circular plot of $500 \mathrm{~m}^{2}$ : Diversity woody stratum, carbon storage (upper-stem $\geq 10 \mathrm{~cm} \mathrm{DBH}$, high saplings between $5-10 \mathrm{~cm} \mathrm{DBH}$ ). 4 subplots of $0.25 \mathrm{~m} 2$ : Carbon storage in the herbaceous stratum. 3 subplot of $0.25 \mathrm{~m}^{2}$ : Carbon storage in litterfall. 3 Trial pits $50 \mathrm{~cm}$ : Organic carbon in soil. 1 Microtrialpit $30 \mathrm{~cm}$ :Soil bulk density.

Fig. 1. Scheme of temporary sample plot (TSP).

For the delimitation of circular plots, central points were randomly located and a radius size of $12.62 \mathrm{~m}$ was established. Every TSP was geographically referenced.

\section{E. Sampling Method}

In order to estimate the carbon sequestration, 3 
components involved in the storage process were evaluated. The considered components were: aboveground and underground biomass, necromass (litterfall) and soil organic carbon for each evaluated kind of stratum.

Subsections 1 and 2, describe the process for determining the biomass of each kind of stratum. Additionally, in subsection 3, the process for sampling the soil organic carbon is presented. It is important to mention that this process must be performed in both strata (woody and herbaceous).

\section{1) Biomass determination of the woody stratum}

Dasometric variables such as diameter at breast height $(\mathrm{DBH})$ and height of all inventoried trees from the circular plot were measured. The DBH values were determined using a diametric tape. The circumference of the stem at $1.30 \mathrm{~m}$ above ground was measured. The diameter was determined using the circumference formula, whereas the height was determined using a clinometer and diametric tape as a measurement tools.

On the other way, the biomass of litterfall was determined from the collection of dead material (leaves, branches and twigs that do not exceed $2.5 \mathrm{~cm}$ of diameter) located in the 3 subplots (Fig. 1) [19]. The samples were weighed and the average was considered as the wet weight of litterfall. A subsample of $200 \mathrm{~g}$ was extracted to determine the content of dry matter (DM) in the laboratory.

\section{2) Biomass determination of the herbaceous stratum}

Herbaceous stratum biomass was determined by collecting all the herbaceous material from 4 subplots located in the circular plot (Fig. 1). The samples were weighed and the average value was recorded as the wet weight. A subsample of $200 \mathrm{~g}$ was extracted to determine the dry weight of the sample in the laboratory.

\section{3) Soil organic carbon}

The determination of soil organic carbonin the 3 trial pits located in the TSP was carried out using a soil sampler tube. Samples of soil at a depth of $0-20 \mathrm{~cm}$ were collected. The samples were homogenized and a subsample of $200 \mathrm{~g}$ was taken to determine, in the laboratory, the organic carbon content.

The apparent density of the soil (BD) was calculated through the cylinder method described by Jadan, 2013 [19]. Cilinder method is defined as the weight per unit volume of soil.

\section{F. EstimationMethod of Carbon Storage}

The steps for estimating carbon sequestration depend on the storage component. In this way, in the woody stratum, for the determination of aboveground and underground biomass, allometric equations were used. Whereas, in the herbaceous stratum, the dry weight of the sample was used as basis. The methodology for both cases is summarized below:

\section{1) Woody stratum biomass estimation}

Once the biomass was calculated, several allometric equations(equations according to IPCC, 2003 [14]) are used as a reliable estimation source, because they have consistency, transparency and rigor.

Several equations whose coefficient of determination $\left(\mathrm{R}^{2}\right)$ is greater than $90 \%$ were used. This means that the fit of the model is high, guaranteeing their use [20]. All results were expressed in tons of biomass per tree.

Table II summarized the allometric equations used in this stage.

TABLE II: ALLOMETRIC EQUATIONS USED FOR THE BIOMASS DETERMINATION OF WOODY STRATUM

\begin{tabular}{lll}
\hline \hline Description & \multicolumn{1}{c}{ Allometricequations } & Reference \\
\hline \hline Cordiaalliodora & $A B=10 \exp (-0.76+2.38 \times \log 10(D))$ & Andrade et al. cited in[21] \\
Bactrisgasipaes & $A B=0.74 \times h^{2}$ & {$[22]$} \\
Inga sp. & $A B=10^{[-1.0+2.3 \times \log (D H B)]}$ & {$[23]$} \\
Cassia grandis, & $\log A B=-2.2+0.08 D-6.2 \times 10^{-4} D^{2}$ & Ruiz, 2001 citedin $[18]$ \\
Moist Forest * & $A B=\exp \left[-2.4090+0.9522 \ln \left(D^{2} H S\right)\right]$ & Brown et al. (1989) cited \\
Several species & $A B=21.30-6.95 \times D H B+0.74 \times D H B^{2} v$ & {$[23]$} \\
Fruit trees ** & $A B=10^{(-1.11+2.64 \times \log (D H B))}$ & Segura et al. citedin[24] \\
Roots & $R B=\exp (-1.0587+0.8836 \times \ln A B)$ & {$[14]$} \\
\hline \hline
\end{tabular}

Note: * (150 - $4000 \mathrm{~mm}$ year); ** DBH (1.9 - 46.5), AB: aboveground biomass, D: DBH (diameter at breast height in cm) H: Height (m) S: density wood $\left(\mathrm{g} / \mathrm{m}^{3}\right)\left(\mathrm{t} / \mathrm{m}^{3}\right)$ exp: exponential; $\log 10$ : logarithm base 10 , ln: natural logarithm.

The litterfall biomass was calculated based on the percentage of dry matter, which was determined in the laboratory. The expression (2) cited by Jadan [19] was use:

$$
L B=D W S / W W S \times F W S
$$

where, $L B$ : litterfall biomass, DWS: dry weight of the subsample (g), WWS: wet weight of the subsample (g), FWS: fresh weight of the sample $(\mathrm{g})$.

Obtained data from aboveground biomass, roots and litterfall were expressed in tons per hectare.

\section{2) Herbaceous stratum biomass estimation}

The estimated biomass of the herbaceous stratum was obtained by applying the expression (3). This expression is based on the dry weight determined in the laboratory.

$$
H B=D W S / W W S \times F W S
$$

where, HB: herbaceous stratum biomass, DWS: dry weight of the subsample $(\mathrm{g})$, WWS: wet weight of the subsample $(\mathrm{g})$, FWS: fresh weight of the sample $(\mathrm{g})$.

In the case of underground biomass (root) of the herbaceous stratum, the proposal of MacDiken, cited in [18], was applied. It recommends a relationship of 0.15 between root biomass and aboveground biomass. Therefore, the root biomass $(\mathrm{HBr})$ corresponds to $15 \%$ of the herbaceous stratum biomass. After calculating the biomass of each component of carbon storage in woody and herbaceous stratum, total 
biomass per soil use system (t/ha) was calculated as explained in Table III.

TABLE III: MATHEMATICAL EQUATIONS USED to ESTIMATE THE TOTAL BIOMASS OF SUS PASTURES WITH AND WITHOUT SHADE

\begin{tabular}{lc}
\hline \hline Soil use system & Total biomass \\
\hline Pastures with shade & $T B=A B+R B+L B+H B+H B r$ \\
Pastures without shade & $T B=H B+H B r$ \\
\hline
\end{tabular}

Note: $T B$ : total biomass (t/ha); $A B$ : aboveground biomass, RB: roods biomass; $L B$ : litterfall biomass; $H B$ : herbaceous stratum biomass; $H B r$ : biomass of roots from herbaceous stratum

\section{3) Calculation of total carbon storage}

In this step, the biomass values must be converted to carbon units $(\mathrm{Mg} / \mathrm{C} / \mathrm{ha})$. Then, the fraction 0.5 is applied over these values [14]. This means that only $50 \%$ of the biomass corresponds to the stored carbon.

Additionally, the soil organic carbon was determined using expression (4).

$$
S O C=(D W / V) \times C \times S D
$$

where, SOC: soil organic carbon, DW: dry weight of soil (g), $\mathrm{V}$ : volume of cylinder $\left(\mathrm{cm}^{3}\right), \mathrm{C}$ : organic carbon obtained in the laboratory $(\%), \mathrm{SD}$ : sampling depth $(\mathrm{cm})$.

Finally, the total carbon storage $(\mathrm{Mg} / \mathrm{C} / \mathrm{ha})$ in each soil use system was determined by adding the carbon stored in the biomass and the soil organic carbon. During this step, the expression (5) was applied.

$$
T C S=(T B \times 0.5)+S O C
$$

where, TCS: total carbon storage $(\mathrm{Mg} / \mathrm{C} / \mathrm{ha}), T B$ : total biomass (t/ha), SOC: soil organic carbon.

\section{4) Conversion of carbon units to equivalent carbon dioxide $\mathrm{CO}_{2} \mathrm{e}$}

According to Yepes et al. [13], the $\mathrm{CO}_{2} \mathrm{e}$ is calculated based on the global warming potential of greenhouse gases. The expression (6) taken from IPCC [14], [15] was used in this process:

$$
\mathrm{CO}_{2} \mathrm{e}=T S C \times(A W C / S W C
$$

where, $\mathrm{CO}_{2} \mathrm{e}$ : carbondioxide (t/CO $\left.\mathrm{e} / \mathrm{ha}\right), T S C$ : total stored carbon, $A W C$ : atomic weight of carbon molecule (44), $S W C$ : specific weight of carbon (12).

\section{RESULTS}

In order to determinate the capability for carbon capture and storage of two soil use systems (pastures with and without shade), an exploratory study that included field tests was conducted. Next subsections present the obtained results of the performed experiments.

\section{A. Carbon Storage in Different Types of Trees}

Once the inventory of trees was determined in 3 towns of the study area, they were classified according to their utility. Consequently, it was determined 6 categories of trees. The established categories were:

1) Fodder trees for example the Trichantheragigantean.
2) Fruits trees like lemon, guava, orange, etc.

3) Timber trees such as Cordiaalliodora, Guareakunthiana, Ocoteaaciphylla, Tabebuiachrysantha, Vochysiabraceliniae, Cedrelaodorata, Junglansspp, Pollalesta discolor, among others.

4) Industrial trees as Castillaelastic.

5) Ornamental trees category that refers to Crescentiacujete Linneo, because this specie does not have commercial relevance but, it is used for beautifying the landscape.

6) Other category that groups some kind of trees that do not have any relevance, like the Ficussp, Cassia sp and others.

Table IV shows the carbon storage capability of different types of trees found in the pastures with shade in Arosemena Tola. It is possible to see that the greatest amount of carbon stored was recorded by the industrial category of trees (743.58 Mg/C/tree). To the date of this research, industrial category of trees could store $2728.93 \mathrm{t} / \mathrm{CO}_{2} \mathrm{e}$.

On the other hand, the category with lesser storage was the Fruits trees one. This category was able to store $123.40 \mathrm{Mg} / \mathrm{C}$ and $452.89 \mathrm{t} / \mathrm{CO}_{2} \mathrm{e}$ of carbon and equivalent dioxide carbon respectively.

TABLE IV: AVERAGEOF CARBON STORAGE IN DIFFERENT CATEGORIES OF TREES. DATA OBTAINED FROM AROSEMANA TOLA TOWN. SUMACO BIOSPHERE RESERVE, ECUADOR

\begin{tabular}{lcc}
\hline \hline Category & $\begin{array}{c}\text { Carbon } \\
\mathrm{Mg} / \mathrm{C} / \mathrm{tree}\end{array}$ & $\begin{array}{c}\text { Equivalent dioxide carbon } \\
\mathrm{t} / \mathrm{CO}_{2} \mathrm{e} / \text { tree }\end{array}$ \\
\hline Fodder trees & 150.28 & 551.53 \\
Fruit trees & 123.40 & 452.89 \\
Timber trees & 262.64 & 963.91 \\
Industrial trees & 743.58 & 2728.93 \\
Other & 254.70 & 934.75 \\
\hline \hline
\end{tabular}

In Archidonatown, only 2 categories of trees were determined. As it can see in Table 5, fruit trees category store more carbon than timber one $(127.39 v s .49 .41$ of $\mathrm{Mg} / \mathrm{C} /$ tree respectively).Same tendency was observed for the $\mathrm{CO}_{2} \mathrm{e}$ values (Table V).

These results do not show the real scenery because, it is not common that fruit trees that normally are smaller and thinner than timber trees, are capable of store more quantity of carbon. These results could be justified due to the fact that timber trees are relatively young then; their stored carbon would be obviously lesser than fruit trees.

TABLE V: AVERAGE OF CARBON STORAGE IN DIFFERENT CATEGORIES OF TREES. DATA OBTAINED FROM ARCHIDONA TOWN. SUMACO BIOSPHERE RESERVE, ECUADOR

\begin{tabular}{lcc}
\hline \hline Category & $\begin{array}{c}\text { Carbon } \\
\mathrm{Mg} / \mathrm{C} / \mathrm{tree}\end{array}$ & $\begin{array}{c}\text { Dioxide carbon estimated } \\
\mathrm{t} / \mathrm{CO}_{2} \mathrm{e} / \text { tree }\end{array}$ \\
\hline Fruit trees & 127.39 & 467.53 \\
Timber trees & 49.41 & 181.32 \\
\hline \hline
\end{tabular}

It is important to note that considering the biodiversity point of view, this town clearly shows less diversity of its woody stratum regarding the previously analyzed town (Arosemena Tola). This feature allows reinforce the previous analysis. The presences of more quantity of young trees, is due that possibly, old trees were already felled and the timber 
was commercialized. This could indicate that the real purpose of the trees presence in the pasture has a commercial purpose. Therefore, the carbon sequestered by this categories of trees, eventually will be returned to the atmosphere through deforestation activities.

Finally, in Tenatown were determined 6 categories of trees. The industrial trees, timber trees and fodder trees occupied the first three positions regarding their ability for storing carbon $(558.66,210.80$ and $158.18 \mathrm{Mg} / \mathrm{C} /$ tree $)$. The last position was occupied by the ornamental trees category with $56.05 \mathrm{Mg} / \mathrm{C} /$ tree. Regarding thestored $\mathrm{CO}_{2} \mathrm{e}$, the industrial trees category presented the highest value and the ornamental category the lesser one (Table VI).

TABLE VI: AVERAGE OF CARBON STORAGE IN DIFFERENT CATEGORIES OF TREeS. DATA OBTAINED FROM TENA TOWN. SumaCo BIOSPHERE RESERVE, ECUADOR

\begin{tabular}{lcc}
\hline \hline Category & $\begin{array}{c}\text { Carbon } \\
\mathrm{Mg} / \mathrm{C} / \text { tree }\end{array}$ & $\begin{array}{c}\text { Dioxide carbon estimated } \\
\mathrm{t} / \mathrm{CO}_{2} \mathrm{e} / \text { tree }\end{array}$ \\
\hline Fodder trees & 158.18 & 580.52 \\
Fruit trees & 81.10 & 297.65 \\
Timber trees & 210.80 & 773.63 \\
Industrial trees & 458.66 & 1683.26 \\
Ornamental trees & 56.05 & 205.69 \\
Other & 65.54 & 240.53 \\
\hline \hline
\end{tabular}

B. Carbon Storage in the Soil Use Systems: Pastures with Shade

TABLE VII: CARBON STORAGE (MG/C/HA) IN THE SOIL USE SYSTEMS PASTURES WITH SHADE. DATA OBTAINED FROM THREE TOWNS OF DE NAPO PROVINCE. SUMACO BIOSPHERE RESERVE, ECUADOR

\begin{tabular}{llcccc}
\hline \hline \multirow{2}{*}{ Storage components } & \multicolumn{4}{c}{ Towns } & \multirow{2}{*}{ Avg } \\
\cline { 2 - 4 } & & AT & A & T & \\
\hline \multirow{2}{*}{ WS } & Aboveground biomass & 32.32 & 14.77 & 26.06 & 24.38 \\
& Root biomass & 5.20 & 2.66 & 4.30 & 4.06 \\
& Litterfall Biomass & 1.56 & 1.87 & 1.14 & 1.52 \\
\hline \multirow{2}{*}{ HS } & Aboveground biomass & 1.62 & 1.60 & 1.66 & 1.63 \\
& Herbaceous root biomass & 0.24 & 0.24 & 0.25 & 0.24 \\
\hline \multirow{4}{*}{ Total carbon on biomass } & 40.94 & 21.14 & 33.41 & 31.83 \\
& Soil organic carbon & 56.52 & 84.11 & 60.72 & 67.12 \\
& Total carbon & 97.46 & 105.25 & 94.14 & 98.95 \\
CO & 357.69 & 386.27 & 345.48 & 363.15 \\
\hline \hline
\end{tabular}

Note: *t/ha, WS: woody stratum, HS: herbaceous stratum, AT: Arosemena Tola, A: Archidona, T: Tena.

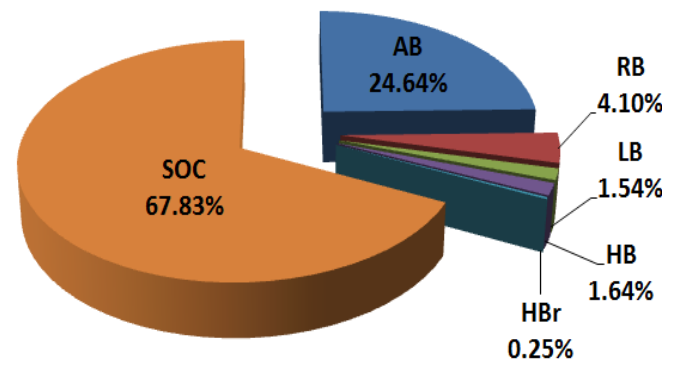

Fig. 2. Carbon storage average in the soil use systems pastures with shade in three towns of de Napo province. Sumaco biosphere reserve, ecuador.
In order to estimate the carbon storage of pastures with shade, each storage component was separately evaluated. Table VII shows the values of all evaluated components in the 3 study sites. Thus, the main carbon storage component was the soil. This component presented an average value of 67.12 $\mathrm{Mg} \mathrm{C} /$ ha for the 3 analyzed towns. At the same time, this value represents the $67.83 \%$ of the total of stored carbon (Fig. 2).

The second position was occupied by the aboveground biomass with an average of $24.38 \mathrm{Mg} / \mathrm{C} / \mathrm{ha}$. This value is equivalent to $24.64 \%$. This component corresponds to the woody stratum.

Regarding the herbaceous stratum, the aboveground biomass reached just $1.62 \mathrm{Mg} / \mathrm{C} /$ ha (i.e. $1.64 \%$ of carbon stored by the pastures with shade, is maintained in this component).

In other way, it is important to highlight that the town with highest value of carbon storage was Archidona. It reached a total of $105.24 \mathrm{Mg} / \mathrm{C} / \mathrm{ha}$ or $386.27 \mathrm{t} / \mathrm{ha} \mathrm{CO}_{2} \mathrm{e}$ (Fig. 3). It also has the soil with the highest organic carbon value $(84.11 \mathrm{Mg} / \mathrm{C} / \mathrm{ha})$. Regarding the carbon from the biomass, this town registered the lesser stored carbon with $21.14 \mathrm{Mg} / \mathrm{C} / \mathrm{ha}$.

Tena was the town with less $\mathrm{CO}_{2} \mathrm{e}(345.48 \mathrm{t} / \mathrm{ha})$.Despite that, it had trees for each identified category. That means that its biodiversity was superior regarding the other towns.

This low carbon storage value could be due to the Tena soil registered the lowest organic carbon quantity, but at the same time the highest amount of carbon stored from the biomass.

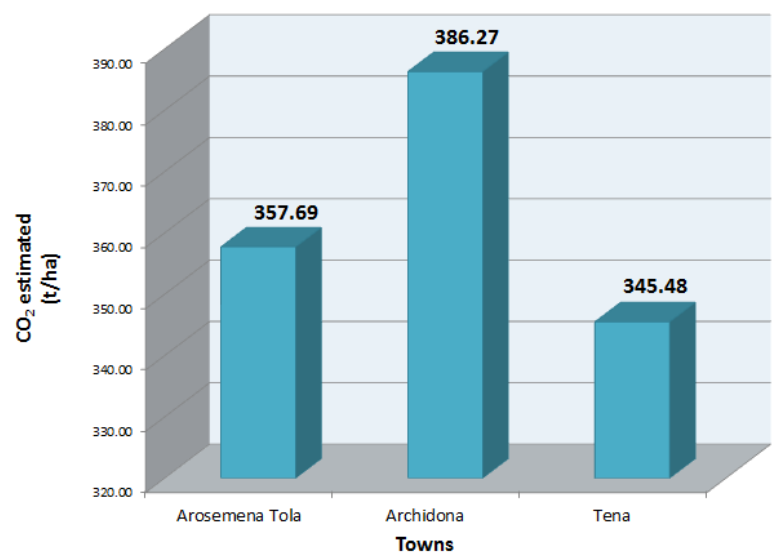

Fig. 3. $\mathrm{CO}_{2} \mathrm{e}(\mathrm{t} / \mathrm{ha})$ in the soil use systems Pastures with shade in three towns of de Napo province. Sumaco Biosphere Reserve, Ecuador.

By analyzing these results with reference to the carbon storage in different types of trees found in Archidona (Table $\mathrm{V}$ and Table VII), it is possible to understand the relationship between the stored carbon ability and the biodiversity, where, lesser biodiversity implicates lesser carbon storage.

\section{Carbon Storage in the Soil Use Systems: Pastures without Shade}

Table VIII shows a summary of the data of carbon storage in pastures without shade. As in the Pastures with shade, the main storage component was the soil. Archidona town had the soil with the highest amount of organic carbon. It registered $77.12 \mathrm{Mg} / \mathrm{C} / \mathrm{ha}$, and also reached the highest value of stored carbon (3.30 Mg/C/ha).

Arosemena Tola got the second position according to carbon stored from the biomass $(2.3930 \mathrm{Mg} / \mathrm{C} / \mathrm{ha})$, but the last position with regard to soil organic carbon. 
Data show that in this soil use system, the most important component is the soil, because almost all of the monitored carbon $(96.16 \%$, Fig. 4) was stored by it. The remaining percentages correspond to carbon storage from aboveground and roots biomass.

TABLE VIII: CARBon STORAGE (MG/C/HA) IN THE SOIL USE SYSTEMS Pastures Without SHADE. DATA OBTAINED FROM THREE TOWNS OF DE NAPO PROVINCE. SUMACO BIOSPHERE RESERVE, ECUADOR

\begin{tabular}{llcccc}
\hline \hline \multirow{2}{*}{ Storage components } & \multicolumn{3}{c}{ Towns } & \multirow{2}{*}{ Avg } \\
\cline { 3 - 5 } & & $\mathrm{AT}$ & $\mathrm{A}$ & $\mathrm{T}$ & \\
\hline \multirow{2}{*}{ HS } & Aboveground biomass & 2.39 & 2.87 & 2.07 & 2.44 \\
& Herbaceous root biomass & 0.36 & 0.43 & 0.31 & 0.37 \\
\hline \multirow{2}{*}{ Total carbon on biomass } & 2.75 & 3.30 & 2.38 & 2.75 \\
& Soil organic carbon & 59.54 & 77.12 & 74.22 & 59.54 \\
Total carbon & 62.30 & 80.42 & 76.60 & 62.30 \\
$\mathrm{CO}_{2} \mathrm{e}^{*}$ & 228.63 & 295.15 & 281.12 & 228.63 \\
\hline \hline
\end{tabular}

Note: *t/ha, HS: herbaceous stratum, AT: Arosemena Tola, A: Archidona, T: Tena.

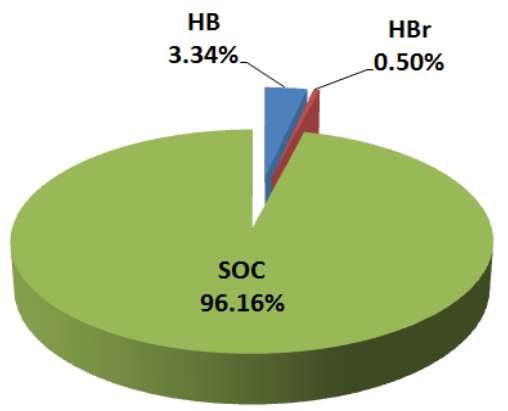

Fig. 4. Carbon storage Average in the soil use systems Pastures without shade in three towns of de Napo province. Sumaco Biosphere Reserve, Ecuador.

The $\mathrm{CO}_{2} \mathrm{e}$ stored in this soil use system was highest in Archidona followed by Tena and ArosemenaTola with 295.15, 281.12 and 228.63 t/ha respectively (Fig. 5).

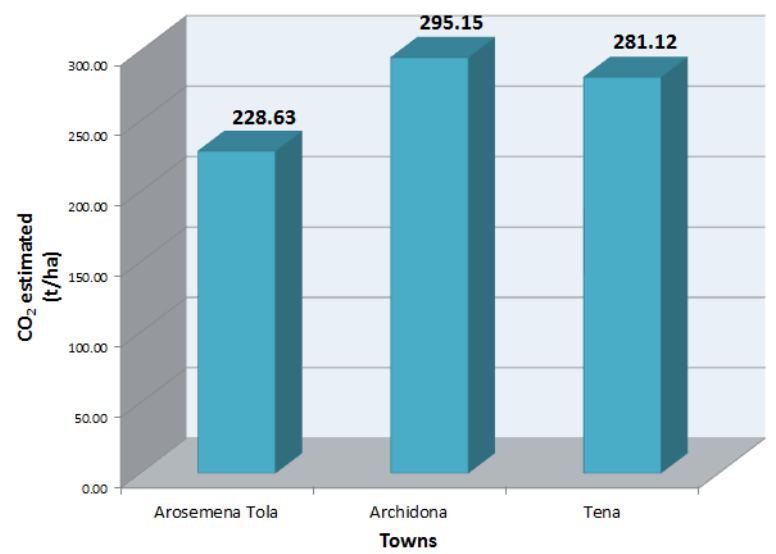

Fig. 5. $\mathrm{CO}_{2} \mathrm{e}(\mathrm{t} / \mathrm{ha})$ in the soil use systems Pastures without shade in three towns of de Napo province. Sumaco Biosphere Reserve, Ecuador.

After analyzing the final results for each soil use system, it is evident that the pastures with shade system, presented superiority in carbon storage capability over the pastures without shade system. The soil component of the shaded system presented the highest percentage of carbon storage however; the carbon stored by the herbaceous stratum was lesser than the herbaceous stratum of the pastures without shade system.
Regarding the pastures production ( $\mathrm{t} / \mathrm{ha}$ ), the shaded system had minor production in reference to the values obtained by pastures without shade. This system registered approximately $0.8 \mathrm{t} / \mathrm{ha}$ more than the shaded system. Therefore, animals in the pastures with shade should stay lees time in compared with the days of grazing in pastures without shade. This fact plays a crucial role at the moment that the producers should choose the suitable system suitable for them.

\section{CONCLUSIONS}

The soil use system with greater capability for carbon storage and capture was the pastures with shade. It reached $363.15 \mathrm{t} / \mathrm{ha} \mathrm{CO}_{2} \mathrm{e}$ and this value was obtained through the existence of trees in the pasture. Therefore, this system can be considered as a quintessential carbon sink because trees have the ability for taking a huge quantity of $\mathrm{CO}_{2}$ through the photosynthesis and transform it into biomass process. And inappropriate handling, majority of this carbon stored in the woody stratum will be returned to the atmosphere (e.g. excessive deforestation, fire, putrefaction, pests and soil use change).

Taking into account the biodiversity, it is necessary to say that the most of found trees species has a forestall relevance from the commercial point of view. This is due to timber activities generate an important income source for the locality. Additionally, the poor disclosure of non timber species (such as: fodder plant, live fence, native trees, etc.) have promoted the species selection only from the economic point of view. Therefore, it is necessary to consider the relevance of the adequate selection of trees considering factors such as: biodiversity, conservation, utility (shade) and beauty landscape.

The soil can be considered as the most important carbon sink. This characteristic is due to the interaction between the soil and the plant root system, because it moves and deposits the carbon into the soil. Thus, for the storing carbon in the soil, it is essential the presence of plants.

Traditional agricultural practices (such as excessive tillage, land clearing, overgrazing, among others) can be considered as responsible of the release of carbon to the atmosphere. Therefore, a sustainable management is necessary to avoid this kind of disturbances.

The valuation of this kind of environmental services allows considering the pastures no only as a fodder source, but as an ecosystem able to offer benefits to society and the planet. This ecosystem participates as a provider of environmental services. The society should pay for the services such as it do it for any other service on the market.

\section{FUTURE WORK}

The future research work focuses on the analysis of the production costs of each soil use system. The main goal of this analysis would be to determine the net incoming of each productive activity developed in both soil use systems. The total incoming should consider the potential income generated by the payment of carbon sequestration as an environmental service traded in the international market.

At the time that this paper was been redacted, some 
surveys for collecting information about income and expenditure of livestock in the two soil use system are being conducted.

\section{REFERENCES}

[1] F. A. Gorrini. (2007). Cambio climático. [Online]. Available: http://www.monografias.com/trabajos52/cambio-climatico/cambio-cl imatico.shtml

[2] W. M. Ciesla, Cambio Climatico Bosques y Ordenacion Forestal: Una Vision de Conjunto, Food \& Agriculture Org., 1996, p. 146.

[3] R. A. Houghton, D. L. Skole, and D. S. Lefkowitz, "Changes in the landscape of Latin America between 1850 and 1985 II. Net release of $\mathrm{CO}_{2}$ to the atmosphere," For. Ecol. Manage., vol. 38, no. 3-4, pp. 173-199, Feb. 1991.

[4] L. Gómez-Echeverri, Cambio Climático y Desarrollo, San José, Costa Rica, 2002.

[5] Food and Agriculture Organization. (2013). Bosques. Artículo en Bligoo.com. [Online]. Available: http://www.rlc.fao.org/es/temas/bosques/

[6] Ministerio de Relaciones Exteriores y Movilidad Humana. (2014). Manejo Sustentable de los Bosques. [Online]. Available: http://cancilleria.gob.ec/manejo-sustentable-de-los-bosques/

[7] MAE, Plan de Manejo del Parque Nacional Sumaco - Napo Galeras, Quito, Ecuador, 2012.

[8] R. Watson, M. Zinyowera, and R. Moss, The Regional Impacts of Climate Change: An Assessment of Vulnerability, 1st ed. Cambridge, United Kingdom, 1998.

[9] IPCC, Uso de la Tierra, Cambio de Uso de la Tierra y Silvicultura, Montreal, Canada, 2000.

[10] D. S. Schimel, "Terrestrial ecosystems and the carbon-cycle," Glob. Chang. Biol., vol. 1, no. 1, pp. 77-91, 1995.

[11] R. Tipper, Mitigation of greenhouse gas emissions by forestry: A review of technical, economic and policy concept, 1996.

[12] A. R. de Freitas, Contribución de las Industrias Forestales al Desarrollo Económico y Social de América Latina. Actas del Primer congreso Latinoamericano IUFRO, 1998.

[13] A. P. Yepes, Á. J. Duque, et al., Protocolo para la estimación nacional y subnacional de biomasa-carbono en Colombia, Bogotá DC, Colombia, 2011, p. 162.

[14] Intergovernmental Panel on Climate Change (IPCC), Good Practice Guidance for Land Use, Land-Use Change and Forestry, 2003.

[15] Intergovernmental Panel on Climate Change (IPCC), "Guidelines for national greenhouse gas inventories," The National Greenhouse Gas Inventories Programme, Japón, 2006.

[16] S. Trumbore, "Belowground cycling of carbon in forests and pastures of Eastern Amazonia," Global Biogeochemical Cycles, vol. 9, no. 4, pp. 515-528, 1995.

[17] Fundación Bio-Parques, Plan de Manejo de la Reserva de Biósfera Sumaco, Tena, Ecuador, 2001.

[18] H. Andrade and M. Ibrahim, "Cómo monitorear el secuestro de carbono en los sistemas silvopastoriles," Agroforestería en las Américas, Turrialba, Costa Rica, vol. 10, 2003.

[19] Á. O. J. Maza, "Influencia del uso de la tierra con cultivos de cacao, chakras y bosque primario, sobre la diversidad, almacenamiento de carbono y productividad en la Reserva de la Biosfera Sumaco, Ecuador," Tesis inédita de Maestria, CATIE, Turrialba, Costa Rica, 2013.
[20] M. Segura and H. Andrade, "Cómo construir modelos alométricos de volumen, biomasa o carbono de especies leñosas perennes? How to develop biomass models of woody perennials species,' Agroforestería en las Américas, Turrialba, Costa Rica, 2008.

[21] N. Arce and E. Ortiz, "Existencias de carbono en charrales y sistemas agroforestales de cacao y banano de fincas indígenas bribri y cabécar de Talamanca, Costa Rica," Agroforestería en las Américas, Turrialba, Costa Rica, 2008.

[22] L. Szott, L. Arevalo, and J. Perez, "Allometric relationships in pijuayo (Bactris gasipaes HBK)," in IV Congreso Internacional Sobre Biología, Agronomía e Industrializacíon Del Pijuayo, 1993.

[23] M. Segura, M. Kanninen, and D. Suárez, "Allometric models for estimating aboveground biomass of shade trees and coffee bushes grown together," Agrofor. Syst., vol. 68, issue 2, pp. 143-150, 2006.

[24] H. Andrade and M. Segura, "Valoración biofísica y financiera de la fijación de carbono por uso del suelo en fincas cacaoteras indígenas de Talamanca, Costa Rica," Agroforestería en las Américas, Turrialba, Costa Rica, 2008

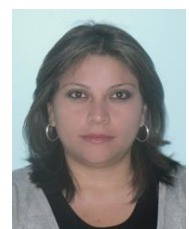

Jimenez G. Alejandra was born in Riobamba, Ecuador in 1985. Her educational background was held at the Escuela Superior Politécnica de Chimborazo - ESPOCH as an animal science engineer in 2010. Currently she is pursuing a master degree of sustainable agriculture in the Universidad de lasFuerzas Armadas - ESPE.

She has worked as an independent consulter. One of the main consultancies was regarding the recovery of promising forage species of Ecuadorian moors. She has participated in several international congresses for presenting scientific publications related with technological and agriculture topics.

Eng. Jimenez belongs to the Animal Science Engineer College. Currently, she is finishing her thesis in order to obtain the master degree in sustainable agriculture.

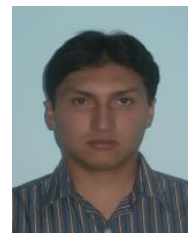

Jimenez Y. Santiago was born in Riobamba, Ecuador in 1985. Currently he is pursuing a master degree of sustainable agriculture in the Universidad de lasFuerzas Armadas - ESPE

$\mathrm{He}$ is a lecturer in ESPOCH and his research interests are related with forage production of cold and warm climate, and Botany. He has participated in several international congresses.

Eng. Jimenez currently is finishing his thesis in order to obtain the master degree in sustainable agriculture.

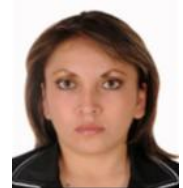

Jimenez G. Cristhy was born in Riobamba, Ecuador in 1980. In 2008, she got the grade of master of informatics engineering at the Pontificia Universidad Católica de Valparaiso-PUCV. In 2013 she got the grade of master in informatics engineering science.

She is a lecturer in ESPOCH and her research interests are related with human computer interaction and semantic web technologies. She has published and participated in several international events.

M.Sc. Jimenez is a member of the Usability Research Group Use CV of the PUCV. Currently, she is working towards her $\mathrm{PhD}$ in informatics engineering at the PUCV - Chile. 